\title{
I.3. EUROCENTRISM IN THE STUDY OF ETHNIC DRESS
}

\author{
SUZANNE BAIZERMAN, JOANNE B. EICHER, \\ AND CATHERINE CERNY
}

In the study of costume by European and American ncholars (hereafter referred to as Euroamerican ${ }^{1}$ ), fashion and Western dress have enjoyed privileged positions. ${ }^{2}$ American and European museum costume collections, exhibitions, and university curricula largely reflect the predilections of a society that has given precedence to the status and lifestyle of the middle- and upper-class Euroamerican, with much less attention paid to ethnic dress. ${ }^{3}$ With increasing emphasis on cultural pluralism, it becomes oven more critical to integrate the study of ethnic dress within a broader context. ${ }^{4}$...

\section{THE IMPLICATIONS OF \\ BUROCENTRISM ON \\ THE STUDY OF DRESS}

Blas in the study of dress of peoples other than those of one's own culture is difficult to escape. We are laught as children that the way we dress is the way one ought to dress. For Europeans and Americans this lesson has meant that the dress of other times and other places has been studied from an ethnocenIric point of view (just as a member of another cullure might be biased in the study of European and American dress). The term Eurocentric, which has a pejorative connotation, refers to a provincial conieption of the world based on a vantage point that "focuses overwhelmingly on European and Western cultures while giving little attention to Asia, Africa, and Latin America." ${ }^{10}$ To counteract this, recent curriculum reform in U.S. secondary schools and university settings has focused on increasing global awareness and on addressing cultural diversity by extending the scope of study beyond Euroamerican frontiers....

European experiences with the non-European world during the Age of Exploration, ${ }^{12}$ from the fifteenth to the nineteenth century, shaped assumptions about the distinctions between Western and non-Western modes of dress. Whether based on direct observation or written accounts, portraits of the people studied and their dress often yielded inaccurate representations. European aesthetic standards and European perceptions of clothing were applied when representing non-European modes. ${ }^{13}$ When Westerners and non-Westerners were depicted together, their clothing suggested Western dominance and implied justification for this dominance, ${ }^{14}$ as in Figure I.3.1.

By the nineteenth century, Darwin's theory of evolution provided one explanation of this cultural diversity. Social Darwinism applied the evolution metaphor to define developmental stages to societies and their features. ${ }^{15}$ The more politically complex and technologically advanced societies were further up the evolutionary trajectory, and hence more European, than the more simple, traditional societies. ${ }^{16}$ Rosaldo has suggested the bias of this orientation by describing the evolutionary process as "a long, arduous journey upward, culminating in 'us." ${ }^{n 17}$ And, we add by logical extension, "our dress." 


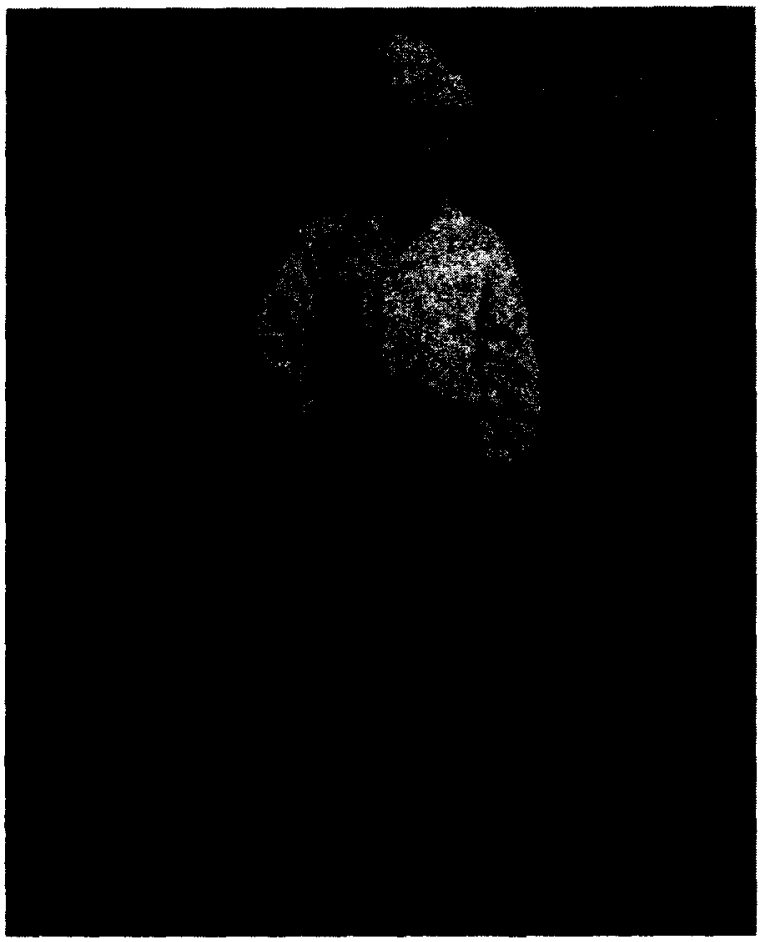

F I G URE 1.3.1. "Stanley and Kalulu," frontispiece, Henry M. Stanley, How I Found Livingstone, 1891. Studio portrait of Henry M. Stanley and Kalulu, ca. 1875. In the Victorian era, photography was the latest technological advance for documenting important events and the lifeways of people outside the European cultural world. It was often used to record modes of dress that seemed strange to people in Europe and North America. However, the photographs were staged and then airbrushed and must be read critically for information on the dress practices of nonEuropean peoples.

Early-twentieth-century costume books linked the dress of early Europeans to the dress of nonEuropean peoples of the world through application of this evolutionary model. Webb, writing in 1907, provided an example:

Man has existed in a civilized condition for a comparative short time, and there remain all kinds of records and illustrations, not to mention actual clothes themselves, which can be consulted or examined. Moreover, primitive man in almost every stage of culture are, or were till quite lately, to be found somewhere in the world, and much can be gleaned from them as to the origin and uses of costume. ${ }^{18}$

Such notions were vital to justifying the paternal stance taken by the Western world as expansionist policies were applied to colonial societies. ${ }^{19}$ Dress was used to secure a society's position along the evolutionary track. Webb's sketch (Figure I.3.2) of Java man and his family, selected for the frontispiece of his book, supports this type of speculation:

Clothes proper are of a later origin, and, as we have already mentioned, would only be adopted for protective purposes after man had lost the greater part of his hairy covering. ${ }^{20}$

At that time, Java man was the earliest known man with human physical features. The implication of this view is that dress at the more primitive stages is somehow inferior or less worthy of serious study, except to the extent that it sheds light on more advanced civilizations.

Dress was touted as a visible manifestation of the civilized state of being, of cultural superiority where advancement was defined in terms of superior eco. nomic development and global dominance. Modifying dress practices of the colonized to parallel those of the West was seen as a way of extending civiliza. tion. Social Darwinism justified the colonial attitude of the Euroamerican to other people of the world. This tone is apparent in the Carpenter's 1908 educa. tional reader that describes the dependence of the U.S. apparel industry on raw materials from other countries. Carpenter commented in the introductory chapter:

As we journey from place to place, we shall be able to study every stage in the building up of this great industry, finding the savages of the wilds still wearing the scanty clothing of early ages, and those a little more advanced making their garments according to the rude fashions that our ancestors followed. In different countries we shall see how the materials are produced, and, in our 
great factories and workshops, how they are transformed into the garments sold in our stores. ${ }^{21}$

This account of global interdependence was framed by the assumption:

We now consider the use of clothing a sign of civilization, and look upon it as one of the chief things that mark our superiority to the rest of the animal creation, and to such of the human race as are less clad than ourselves. ${ }^{22}$

Thus, the notions of Social Darwinism affected the evaluations of dress and technology of other

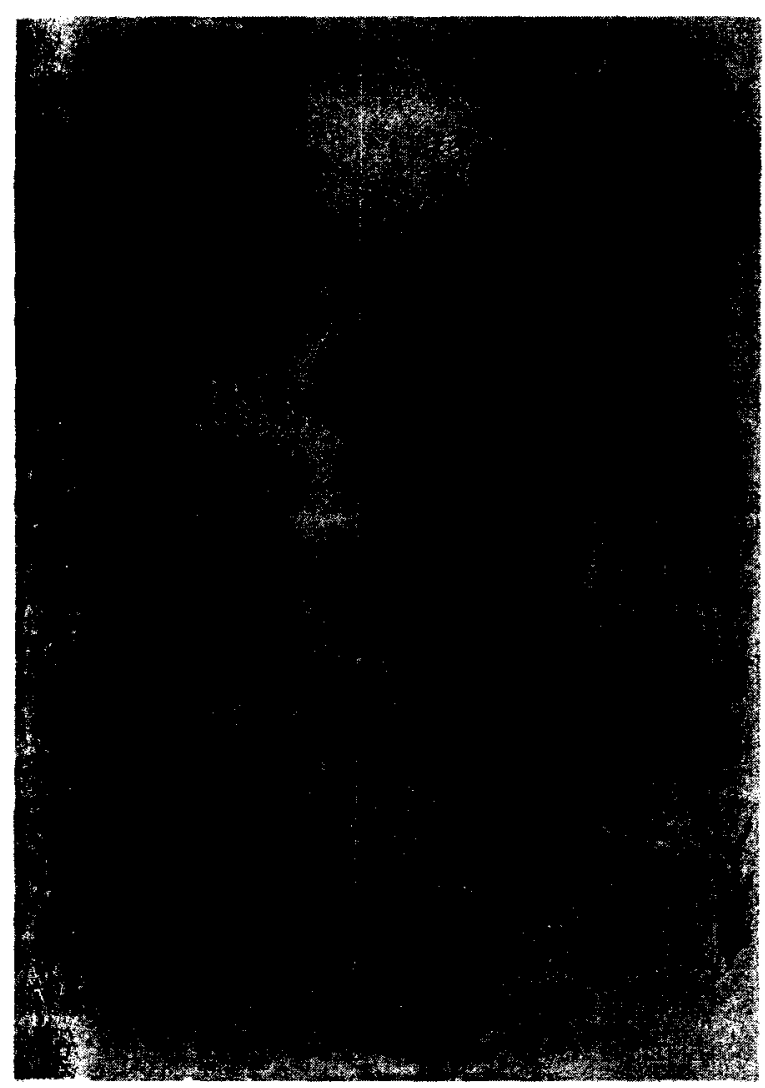

H I GURE 1.3.2. "Very Early Man in Java," Plate I, Wilfred Webb, The Heritage of Dress, 1907, 9. Early ethnocentric depictions of ancient human ancestors in the far reaches of the globe imagined them with a simple material culture that did not include clothing, but did include male hair rutting. cultures. Uncut rectangular garments became precursors to more complex, cut-and-sewn forms with Western dress indicative of social and moral advancement. Backstrap looms were seen as less evolved than mechanized treadle looms. ${ }^{23}$ As garments became more complex in design, original purposes of adornment and protection were forgotten. ${ }^{24}$ George Darwin, son of Charles Darwin, described the way in which certain garment features, such as the notched lapels on men's jackets, were vestiges of earlier functional garments' features. ${ }^{25}$ The implication was that as one climbed the evolutionary ladder, clothing forms and technology became more complex, more like those in Western society. ...

Paralleling the history of dress with the development of Western civilization is both misleading and detrimental to understanding the diversity of world dress. The study of Western civilization may be useful in documenting European philosophy and history, but we cannot assume that the history of Western dress follows the same trajectory. We propose a more broadly based approach that emphasizes cultural and aesthetic pluralism....

\section{EUROCENTRIC ASSUMPTIONS INHERENT IN TERMINOLOGY}

In 1980, the need for a definition of ethnic dress was addressed by Roach and Musa in "New Perspectives on the History of Western Dress." They suggested a multidisciplinary approach to the study of Western dress, specifying Western dress as "only dress that is clearly identifiable as being within the continuous sphere of influence of Western European fashionable dress." 32 They recognized that "those things called European are the end-products of hundreds of years of intermixing of elements from many cultures"33 and that "Western" dress has been adopted by peoples outside of Europe, yet they also acknowledged the difficulty in qualifying mixtures of Western and non-Western dress as part of Western European fashionable dress and relegated analysis of "mutations and hybrids" to the study of indigenous society. Correspondingly, they excluded 
clothing practices of indigenous European folk from their definition of European dress by arguing that the myriad variations were responses to provincial customs and needs, rather than to the global phenomenon of fashion. They left open, as beyond the scope of their work, specifying and discussing what did not fall into the category of Western European fashionable dress. Therefore in this paper, we focus on the residual category that, according to anthropologist Bernard Cohn, probably encompasses the dress of nine-tenths of the world's people today, not to mention those of ancient times. ${ }^{34}$

Efforts to describe that which lies outside fashionable Western dress have generated a profusion of terms. In addition to ethnic, other terms commonly used are non-Western, peasant, folk, primitive, tribal, exotic, regional, national, nonindustrial, and traditional. The meanings that underlie these terms tell as much about the perceptions and attitudes of the Euroamerican who applied them as about the dress described. As we examine each term, we uncover assumptions that show the shifting relationship between Euroamericans and others outside this domain and demonstrate the scope of a Eurocentric view of the world.

Qualifying adjectives, such as primitive, savage, and exotic, often indicate dress of people less familiar or less known. They tap our own myths and fantasies, with connotations stemming from Puritan notions about pagans and heathens. ${ }^{35}$ Labels which use these terms promote stereotypes that allow us to dehumanize the people described and distance ourselves from them. The terms non-Western and nonindustrial no doubt arose in an attempt to bring a more objective, neutral approach to the study of dress, an approach that respected the cultural authenticity of a people, but at the same time acknowledged their uniqueness in a modern European world. However, as time has seen their broadening application, these terms have likewise provided a residual designation, into which the different and the unfamiliar are discarded. The prefix non gives them a built-in negative. Where Western and industrial are associated with the Euroamerican, and thus with the progress of civilization, the negative prefix, as in non-Western, implies clothing traditions that have fallen short of the standard of modernity and technological sophistication. Today, the appropriateness of this distinction is even more questionable as the reach of the modern in. dustrial world (e.g., radio and television) extends to many remote areas.

Close attention to the term costume reveals it an a highly problematic one. To some, the term costume contains an inherent bias that differentiates the unfamiliar from the familiar. In English usage, the term costume often refers to exceptional dress, dress outside the context of everyday life: Hallow. een costume, masquerade costume, theater costume. In these contexts costume speaks to an assumed identity in opposition to everyday roles. The term costume is sometimes used to mean the dress of all people and identifies historic repositories (e.g., The Metropolitan Museum of Art's Costume Institute) and textbooks on the Western tradition of dress (e.g." Payne's History of Costume). However, clothing and adornment from other times and other places may be referred to as costume-e.g., primitive costume, ethnic costume, folk costume - to mark distance, in a Eurocentric fashion, from our experience. ${ }^{36}$

While terminology establishes boundaries between Euroamerican society and the rest of the world, it may be more difficult to see how it also validates a hierarchical relationship between a powerful Euroamerican elite and a less powerful Other. Terms such as primitive, tribal, folk, exotic, native, in. digenous, and peasant may connote the patronizing perspective of the colonizer and the implied inferiority of the colonized. Furthermore, terms such as exotic, tribal, or folk seem inappropriate when applied to the courtly dress of non-European civilizations. They deny a complexity and elegance that otherwise exemplify dress, for instance, among the nobility of the Han Dynasty or of the ancient Maya, both of which developed independent of European influence. The study of dress can actually acknowledge the cultural sophistication of other societies.

At times, the dress of those ascribed this inferior status has been described as unchanging, frozen in time, unaffected by outside influences. In 1959, Bradshaw noted that many of the examples of world dress 
Illustrated in her book "are still worn today and in tome cases they have not changed for several centuries, so proving that the dress is the one most suited to its environment. . . ${ }^{n 37}$ The term traditional dress connotes a static image and often provokes a romantic image. Traditional dress is often considered "authentic," implying that the dress tradition has been handed down from a past and remains free from the influence of modern civilization. Yet many current studies now acknowledge the impact of industrialization upon dress in remote parts of the world. ${ }^{38}$

Rather, all societies have complex histories. As Sally Price points out:

Recent research that applies historical and anthropological sophistication to materials in Africa, Oceania, and the Americas is building a persuasive case that the nonhistorical reputation of primitive societies is a construction of Western cultural biases and the limitations of traditional Western modes of scholarship. ${ }^{39}$

To counter Eurocentrism, we must recognize that contemporary styles of dress are the consequence of a history in which internal and external forces of change have selectively shaped the form. This applies equally to Euroamerican and non-Euroamerican dress. Whether or not change occurs slowly or rapidly, is internally or externally determined, dress traditions evolve to reflect social change, as new materials, technologies, and ideologies are introduced and have an impact. For example, the clothing styles of the modern Maya of Mexico and Guatemala are viewed as traditional, yet they are hybrids of indigenous Mesoamerican dress and styles introduced by Spaniards during the sixteenth through nineteenth centuries (Figure I.3.3). ${ }^{40}$ Anthony Shay aptly describes Croatian folk dress as "layered": materials, ornamentation, and garments have been added or modified in response to cross-cultural influences (including Roman, Renaissance European, and Ottoman) since initial settlement. ${ }^{41}$ Similarly, Amish dress, with the incorporation of historic European components, has been classified as a variation of Euroamerican dress. However, like Mayan and Croatian

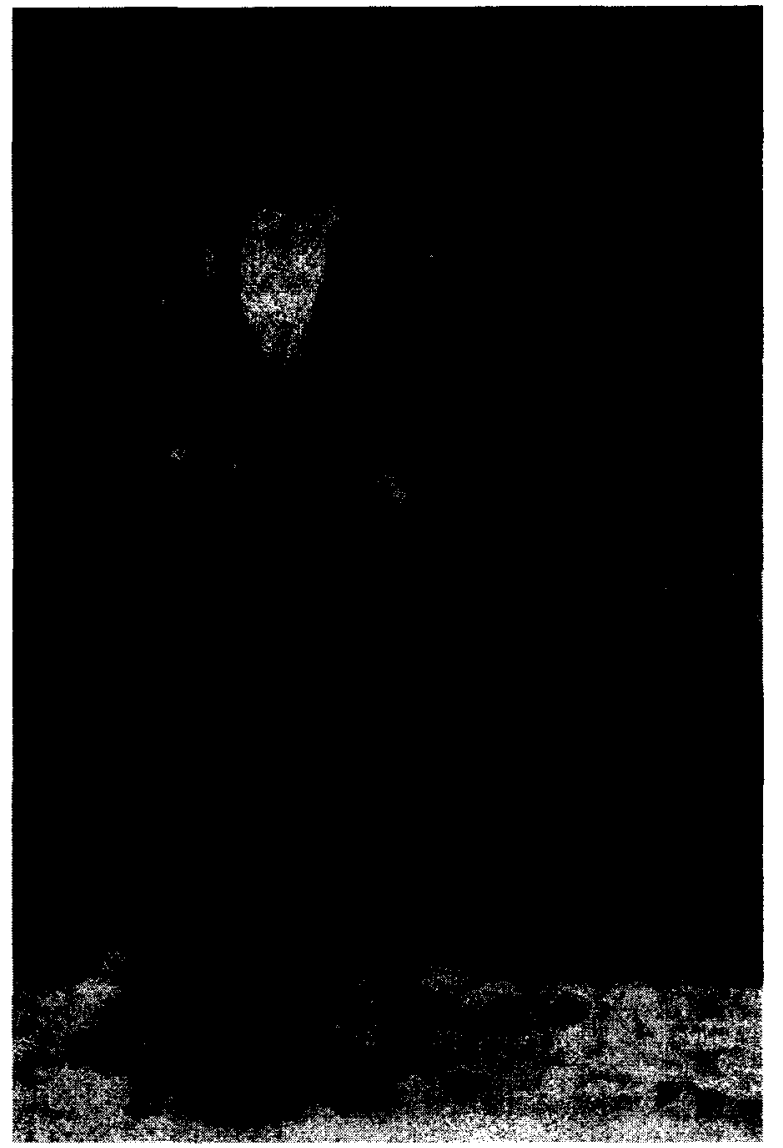

FIGURE 1.3.3. Guatemalan man from Chichicastenango, 1935.

dress, elements of dress have been borrowed, incorporated, and thus transformed into a new expression -Amish ethnic dress. All three cases exemplify a process which Tonye Erekosima and Joanne Eicher have termed cultural authentication. ${ }^{42}$

The Eurocentric view promoted the stereotype of traditional dress as a rigidly prescribed costume form with few variations to differentiate the social roles and relationships within a community. Ethnic dress was often perceived by outsiders as uniform, only linked to identification of the wearer's ethnicity. As Shelagh Weir's 1989 study of Palestinian village costume so clearly pointed out, the problem may lie with not being trained to see subtle differences. ${ }^{43}$ Within a community, distinctions among group 
members can identify other categories in addition to ethnicity, such as age, marital status, and religious or political affiliation (Figure I.3.4). ${ }^{44}$

The term national costume, by implying geographic specificity, gives the illusion of a less value-laden term. At the same time, however, it sustains assumptions about timelessness and ethnicity. The emergence of the term can be correlated with political and social developments of nineteenth- and twentiethcentury Europe, a time of considerable upheaval precipitated by the Industrial Revolution. The establishment of national dress signified political and/or social autonomy of a people becoming embedded in the romanticism of the period. The term reflected attempts to preserve cultural traditions and social institutions threatened by increasing modernization. Sentiment and nostalgia surrounding national dress reinforced efforts to perpetuate national identity. ${ }^{45}$

This connection to nation-state boundaries has made the concept of national costume valuable in a specific context but of limited utility as an overarching term to describe the particular variants of world dress. Today, political boundaries often blur the distinctiveness of national dress. As in the case of Yoruba dress in West Africa, geographic and cultural boundaries of a society may extend beyond the political boundaries of any one nation. The dress of certain peoples in the south of Mexico are culturally related to others in Guatemala, descendants of the ancient Maya, but political boundaries have largely separated the study of the dress of the region into "Mexican Dress" and "Guatemalan Dress." One exhibition, "Beyond Boundaries: Highland Maya Dress at the Museum of International Folk Art," successfully transcended national boundaries and examined dress across national boundaries within a culturally defined region. ${ }^{46}$

At first glance, the term regional dress has an appeal; it is neutral to Eurocentric biases, is applicable to various contexts, and can transcend national boundaries. Under closer examination, the term is ambiguous, for all dress has regional specificity. Factors such as climate, terrain, and dress practices customize even Western dress to specific locales, communities, and subcommunities, in subtle ways.

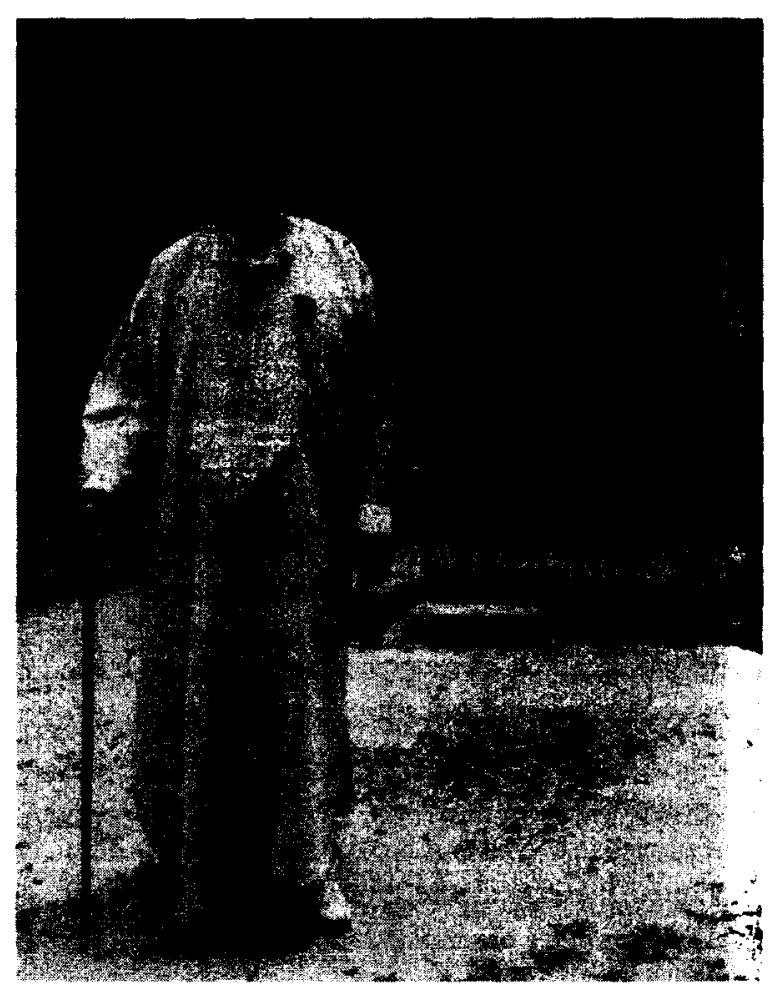

FIGURE I.3.4. Kalabari man wearing a garment called doni. Distinctive dress of members of a cultural group can identify other social categories in addition to their ethnicity. For example, this Kalabari man is identified as a chief according to the cultural codes of dress in Kalabari society, because his ensemble includes the gown known as doni, an English top hat, and a walking stick. See Figure IV.1.3 and associated Reading for further information on the doni.

Regional dress as a term lacks an indication that dress is not just geographically, but also culturally defined. For example, although the form of Amish dress may vary regionally, a common ideology shared among the communities governs its overall use. ${ }^{47}$

We proposed earlier that the term regional dress was more neutral than ethnic dress, ${ }^{48}$ but we now conclude that ethnic dress emerges as the most workable term. It is easily associated with the term ethnic group: "Any group of people who set themselves apart and are set apart from other groups with whom they interact or coexist in terms of some distinctive criterion or criteria which may be linguistic, 
racial or cultural. ${ }^{\text {n9 }}$ Most often an ethnic group will have a name or ethnonym for itself. ${ }^{50}$ Examples of ethnic dress may broadly range from the dress of the Moravians of the Czech Republic, the second generation Japanese (nisei) who wear kimono for the Bon Odori ${ }^{51}$ celebration in California, or the Cakchiquel Maya of Guatemala.

Ethnic can encompass other terms, including folk, traditional, regional, and non-Western. It can be broadened to encompass defined communities such is the Amish who, because of their association with turopean dress elements, have not usually been characterized as ethnic. Likewise, it can encompass Buropean dress elements found on other continents, xuch as the Kalabari in Nigeria or Sino-Japanese eleinents found in Euroamerican fashion. ${ }^{52}$ Ethnic dress nymbolizes collective identity, identifying the wearer both within and beyond the community. Further, in research settings, the term ethnic is usually associated with an emic perspective, an approach that seeks to reflect the point of view of those inside a particular culture.

However, use of the term ethnic has been problematic. Numerous, inconsistent, and vague definitlons of the term have made it difficult to specify how narrowly or broadly the term can be applied. Because the term has generally been applied to immigrant and Third World peoples, some scholars consider that a politically charged "us versus them" hierarchy is embodied by the term..$^{53}$ Others raise the question: Are we all ethnic? ${ }^{54}$ However, recent theoretical work in the area of ethnicity has emphaNized the processual nature of the term, ${ }^{55}$ transformIng a static concept into a more dynamic one that umbraces change over time.

\section{NOTES}

1. We use Euroamerican to include North and South America, Australia and New Zealand as extensions of Hurope.

2. Note that throughout this paper preference is wiven to the word "dress." We acknowledge that dress may be a troublesome term due to its association with women's garments. However, the use of dress as a gender-free reference to clothing is consistent with English usage as it appears in standard dictionaries, for example, the Oxford English Dictionary (2nd ed.).

3. Similarly, we acknowledge that the study of popular dress within the Euroamerican context has been largely overlooked until recently.

4. CSA [Costume Society of America] members may recall the controversy surrounding the 1989 CSA Symposium on the topic of ethnic dress. Many members questioned the relevance of this topic.

10. Joseph Berger, "Ibn Batuta and Sitar Challenging Columbus and Piano in Schools," New York Times, 12 April 1989.

12. Scholars, such as George W. Stocking, Victorian Anthropology (New York: The Free Press, 1987) have explored the roots of historical understanding to reveal the nature and extent of assumptions that underlay European exploration and colonization.

13. See JoAnne Olian, "Sixteenth-Century Costume Books," Dress 3 (1977), and Eileen Ribeiro, "Introduction," in The Historical Encyclopedia of Costume by A. Racinet (New York: Facts on File Publication, 1988), 1-7.

14. See Margaret T. Hodgen, Early Anthropology in the Sixteenth and Seventeenth Centuries (Philadelphia: University of Pennsylvania Press, 1964).

15. See Cynthia R. Jasper and Mary Ellen RoachHiggins, "History of Costume: Theory and Instruction," Clothing and Textiles Research Journal 5, no. 4 (Summer 1987): 1-6, for a discussion of this issue as it relates to university curriculum.

16. See Edward Burnett Tylor, Primitive Culture: Researches into the Development of Mythology, Philosophy, Religion, Language, Art, and Custom, 5th ed. (Boston: Estes and Lauriat, 1913). He identifies three evolutionary stages: savagery (technology consisted of stone tools and wild foods), barbarism (beginning agriculture and metallurgy), and civilization (begins with introduction of writing).

17. Renato Rosaldo, Culture and Truth: The Remaking of Social Analysis (Boston: Beacon Press, 1989), 31.

18. Wilfred M. Webb, The Heritage of Dress: Being Notes on the History and Evolution of Clothes (London: $\mathrm{E}$. Grant Richards, 1907), 2. 
19. Merwyn S. Garbarino, Sociocultural Theory in Anthropology: A Short History (New York: Holt Rinehart and Winston, 1977), 10.

20. Webb, The Heritage of Dress, 7.

21. Frank George Carpenter, How the World is Clothed (New York: American Book Co., 1908), 10.

22. Ibid., 13-14.

23. George Foster, Culture and Conquest: America's Spanish Heritage (New York: Viking, 1960), 107.

24. During the late nineteenth and early twentieth centuries, there was considerable scholarship questioning the functional origin(s) of dress and its relationship to contemporary circumstance. Scholars discussed the validity of theories by using non-European practices as indicative of earlier evolutionary or developmental stages. See, for example, Knight Dunlap, "The Development and Function of Clothing," Journal of General Psychology 1 (1928): 64-78; Edward Westermarke, The History of Human Marriage (New York: The Allerton Book Co., 1992); and W. I. Thomas; "The Psychology of Modesty and Clothing," The American Journal of Sociology 5 (1899): 246-266. That the origins of dress continues to be a concern is shown in 1980 s textbooks on clothing. See Marilyn Horn and Lois M. Gurel, The Second Skin, 3rd ed. (Boston: Houghton Mifflin Co., 1981), 10-35.

25. George Darwin, "Development in Dress," Macmillan's Magazine (September 1872): 410.

32. Mary Ellen Roach and Kathleen Ehle Musa, New Perspectives on the History of Western Dress (New York: Nutriguides, 1980), 5 .

33. Ibid.

34. Bernard Cohn, An Anthropologist Among the Historians and Other Essays (Oxford: Oxford University Press, 1987), 35 .

35. In the late nineteenth century, the terms primitive, barbarian, and savage were used to describe those who were believed to live in early stages of social and technological development. Most were dark skinned and wore little clothing. Nudity or near nudity led to assumptions about promiscuity and immorality. The primitive, barbarian, or savage represented a contrast to Euroamericans with their own social life and was seen as ancestral to their own civilized state. The semi-clothed state of the diverse indigenous populations challenged basic assumptions about the necessity of modesty and protection in contemporary European dress. A critical discussion of these assumptions in accounting for the origins of clothing can be found in Hilaire Hiler, From Nudity to Raiment (London: W. and G. Foyle, 1929).

36. Using the word costume, especially in reference to the non-Euroamerican, also avoids dealing with the aesthetic, political, social, and economic implications of dress forms and practices within their original settings.

37. Angela Bradshaw, World Costume (London: Adam and Charles Black, 1959).

38. See, for example, Ronald Waterbury, "Embroidery for Tourists," Cloth and Human Experience, edited by Annette B. Weiner and Jane Schneider (Washington, DC: Smithsonian Institution Press, 1989), 243-271, and Cherri M. Pancake, "Gender Boundaries in the Production of Guatemalan Textiles," Dress and Gender: Making and Meaning in Cultural Contexts, ed. by Ruth Barnes and Joanne B. Eicher (Oxford: Berg Publishers, Inc., 1992), 76-91.

39. Sally Price. Primitive Art in Civilized Places (Chicago: University of Chicago Press, 1989), 67.

40. See Abby Sue Fisher, "Manila Galleon Trade Textiles: Cross-Cultural Influences on New World Dress," in Textiles as Primary Sources: Proceedings of the First Symposium of the Textiles Society of America (Minneapolis: Textile Society of America, 1988).

41. Anthony Shay, "Traditional Costumes of Croatia: An Introductory Survey," Ormament 3 (1981): 14-20.

42. Tonye V. Erekosima and Joanne B. Eicher, "Kalabari Cut-Thread and Pulled-Thread Cloth: An Example of Cultural Authentication," African Arts 14 (February 1981): 48-51, 81 .

43. Shelagh Weir, Palestinian Dress (London: British Museum, 1989).

44. See Petr Bogatyrev, The Functions of Folk Costume in Moravian Slovakia (1937; reprint, The Hague: Mouton, 1971).

45. See Hugh Trevor-Roper, "The Invention of Tradition: the Highland Tradition of Scotland," in The Invention of Tradition, ed. Eric Hobsbawn and Terence Ranger (Cambridge: Cambridge University Press, 1983), 15-41.

46. Nora Fisher, ed., Beyond Boundaries: Highland Maya Dress at the Museum of International Folk Art (Sante Fe: Museum of New Mexico Press, 1984). 
47. Stephen Scott, Why Do They Dress That Way? (Intercourse, PA: The People's Place/Good Books, 1986).

48. See Suzanne Baizerman, Joanne B. Eicher, and Catherine Cerny, "Ethnic Dress: An Exploration of Terminology with Implications for Research and Teaching" (Paper presented at the annual meeting of the Costume Society of America, Denver, 1989).

49. Charlotte Seymour-Smith, Macmillan Dictionary of Anthropology (London: The Macmillan Press Ltd., 1986).

50. Colin Renfrew, Archaeology and Language: The Puzzle of Indo-European Origins (New York: Cambridge University Press, 1987), 216.

51. A folk dance performed in appreciation of fruitful harvest to the harvest deities. Bon is a particular week in August when the ancestral spirits visit the world of the living. Odori means dance. In Bon Odori, participants dressed in kimonos generally form a large circle and collectively follow a choreographed dance format. The dance is commonly performed prior to, during, and after the Bon week.

52. See Erekosima and Eicher, "Kalabari Cut-Thread and Pulled-Thread Cloth" and Kim and DeLong, "SinoJapanism in Western Women's Fashionable Dress."

53. See J. Sarna, "From Immigrants to Ethnics: Toward a New Theory of Ethnicization," Ethnicity 5 (1978): 370-78.

54. See Elizabeth Tonkin, Maryon McDonald and Malcolm Chapman, History and Ethnicity (New York: Routledge, 1989), 16.

55. See, for example, Malcolm Chapman, Maryon McDonald and Elizabeth Tonkin, "Introduction", History and Ethnicity, 1989, and Renfrew, Archaeology and Language.

\section{B I B L I O G RA P HY}

Baizerman, Suzanne, Joanne B. Eicher, and Catherine Cerny. "Ethnic Dress: An Exploration of Terminology with Implications for Research and Teaching." Paper presented at the annual meeting of The Costume Society of America, Denver, 1989.

Berger, Joseph. "Ibn Batuta and Sitar Challenging Co- lumbus and Piano in Schools." New York Times 12 April 1989.

Bogatyrev, Petr. The Functions of Folk Costume in Moravian Slovakia. 1937. Reprint. The Hague: Mouton, 1971.

Bradshaw, Angela. World Costume. London: Adam and Charles Black, 1959.

Carpenter, Frank George. How the World Is Clothed. New York: American Book Company, 1908.

Chapman, Malcolm, Maryon McDonald, and Elizabeth Tonkin. "Introduction." History and Ethnicity, edited by Elizabeth Tonkin, Maryon McDonald, and Malcolm Chapman. New York: Routledge, 1989.

Cohn, Bernard S. An Anthropologist Among the Historians and Other Essays. Oxford: Oxford University Press, 1987.

Darwin, George. "Development in Dress." Macmillan's Magazine (September 1872): 410-416.

Erekosima, Tonye V. and Joanne B. Eicher. "Kalabari Cut-Thread and Pulled-Threat Cloth: An Example of Cultural Authentication." African Arts 14 (February, 1981): 48-51, 81.

Fisher, Abby Sue. "Manila Galleon Trade Textiles: Cross-Cultural Influences on New World Dress." In Textiles as Primary Sources: Proceedings of the First Symposium of the Textile Society of America, 131-135. Minneapolis, 1988.

Fisher, Nora, ed. Beyond Boundaries: Highland Maya Dress at the Museum of International Folk Art. Santa Fe: Museum of New Mexico Press, 1984.

Foster, George. Culture and Conquest: America's Spanish Heritage. New York: Viking, 1960.

Garbarino, Merwyn S. Sociocultural Theory in Anthropology: A Short History. New York: Holt Rinehart and Winston, 1977.

Hiler, Hilaire. From Nudity to Raiment. London: W. and G. Foyle, 1929.

Hodgen, Margaret T. Early Anthropology in the Sixteenth and Seventeenth Centuries. Philadelphia: University of Pennsylvania Press, 1964.

Jasper, Cynthia R. and Mary Ellen Roach-Higgins. "History of Costume: Theory and Instruction," Clothing and Textiles Research Journal 5, no. 4 (Summer, 1987): 1-6.

Olian, Jo Anne. "Sixteenth-Century Costume Books." Dress 3 (1977): 20-48. 
Payne, Blanche. History of Costume. New York: Harper and Row, 1965.

Price, Sally. Primitive Art in Civilized Places. Chicago: University of Chicago Press, 1989.

Renfrew, Colin. Archaeology and Language: The Puzzle of Indo-European Origins. New York: Cambridge University Press, 1987.

Ribeiro, Eileen. "Introduction." In The Historical Encyclopedia of Costume by A. Racinet, 4-7. New York: Facts on File Publication, 1988.

Roach, Mary Ellen and Kathleen Ehle Musa (now Campbell). New Perspectives on the History of Western Dress. New York: Nutriguides, Inc., 1980.

Rosaldo, Renato. Culture and Truth: The Remaking of Social Analysis. Boston: Beacon Press, 1989.

Sarna, J. "From Immigrants to Ethnics: Toward a New Theory of Ethnicization." Ethnicity s (1978): 370-378.

Seymour-Smith, Charlotte. Macmillan Dictionary of Anthropology. London: The Macmillan Press Ltd., 1986.

Shay, Anthony. "Traditional Costumes of Croatia: An Introductory Survey." Omament 3 (1981): 14-20, 13.

Stocking, George W., Jr. Victorian Anthropology. New York: The Free Press, 1987.
Tonkin, Elizabeth, Maryon McDonald, and Malcolm Chapman, eds. History and Ethnicity. New York: Routledge, 1989.

Trevor-Roper, Hugh. "The Invention of Tradition: The Highland Tradition of Scotland." In The Invention of Tradition, edited by Eric Hobsbawn and Terence Ranger, 15-41. Cambridge, Cambridge University Press, 1983.

Tylor, Edward Burnett. Primitive Culture: Researches into the Development of Mythology, Philosophy, Religion, Language, Art, and Custom. sth ed. Boston: Estes and Lauriat, 1913.

Webb, Wilfred M. The Heritage of Dress: Being Notes on the History and Evolution of Clothes. London: E. Grant Richards, 1907.

Weiner, Annette B. and Jane Schneider. Cloth and $\mathrm{Hu}$ man Experience. Washington, DC: Smithsonian Institution Press, 1989.

Weir, Shelagh. Palestinian Dress. London: British Museum, 1989.

Source: Excerpted from Dress, vol. 20 (1993). Reprinted by permission.

\title{
I.4. MANY DISCIPLINES, MANY REWARDS: INUIT CLOTHING RESEARCH
}

\author{
BETTY KOBAYASHI ISSENMAN
}

Although the Inuit ${ }^{1}$ have inhabited the North American continent, Kalaallit Nunaat (the ancient and modern name for Greenland), and northeastern Siberia for over 4,000 years, their apparel is little known to dwellers of non-northern lands. The garments play a key role for the Inuit: as protection, identification, and culture bearer. The Inuit passed on their technology and wisdom from generation to generation by example and through oral history and legends and have recently begun to record the ancient lore in writing and film. Both oral and written accounts are an invaluable legacy to clothing investigations.

Many physical and social sciences have contributed to the research about Inuit clothing, resulting in the enrichment of our comprehension. From the evidence at hand, we can conclude that the Inuit and their ancestors, over the millennia, created their 